\title{
Comparing Israeli attacks towards Gaza Strip before and after Palestine's accession to the ICC
}

\author{
Dr. Said Talal Aldahshan
}

Al Quds Forum for International and Legal Relations Turkey

\begin{abstract}
In order to search for any changes in the number and type of Israeli attacks on the Gaza Strip after Palestine's accession to the International Criminal Court, a statistical analysis was conducted comparing five years before joining from 2010 to 2014 versus five years after accession from 2015 to 2019. By relying on official statistics issued by the human rights centers, the comparison was made in 1 - the numbers and types of the victims 2- The targets that these attacks hit, and the researcher found, that there was a significant decrease in the number of dead, from (2730) in the first period it decreased to (436) in the second period, In contrast to the number of wounded, which rose from (13948) to (22165) in the second period due to the Great Return March. When comparing the ratio of the dead to the wounded in each period, it was found that it was proportional to (51) wounded, for every (10) dead, which increased dramatically and became (508) wounded for every (10) killed. On the other hand, the number of hit targets from (59155) to $(23,464)$. And the category of targeting cars and motorcycles from (1311) became only (4), which is a percentage closer to zero in this category. All of this confirms that Israel has changed the number and type of its attacks against the Gaza Strip, and the nature of the objectives it intended in both quality and quantity after Palestine joined ICC.
\end{abstract}

Keywords: Israeli attacks, Gaza strip, Civilian casualties, Israeli military behavior, Palestine, Israeli attacks, The International Criminal Court

\section{Introduction:}

After Palestine joined the International Criminal Court in early 2015, a controversy arose among specialists and those interested in the extent to which such accession affected the nature of Israeli attacks toward Palestinian civilians in Gaza Strip. Some have proclaimed that Israel will not change a bit of its military behavior towards civilians. Moreover, And Israel will not care about international law and the International Criminal Court. Others said that Israel and despite this huge support from the United States and all international forums, reckons the court and will change some of the types and quantity of its military practices toward Palestinian civilians, however will not stop completely but will modify its behavior. Others were more optimistic when he said Israel will cease targeting civilians and civilian objects permanently, and will only target positions of resistance and resistance, and possibly, in a defensive framework. All this raised enthusiasm for the researcher to go back to the original sources of monthly and annual official reports of human rights institutions in Palestine regarding the numbers and quality of victims. In addition, the targets that have been fallen and there type, to prepare a statistical study for comparing two equal periods, the period before and after accession. Consequently, this study aims to search for changes in the size and type of the Israeli attacks on the Gaza Strip, And the resulting casualties and losses, and a comparison between the period before Palestine joined the International Criminal Court and the post-accession period ${ }^{(i)}$.

Therefore the researcher have located the study in the Gaza Strip, which is the most frequently targeted Palestinian area by the Israeli army, and the study time has been set at 10 years, five years before accession, the years 2010 to 2014 and five years after accession, from 2015 to 2019. This is in order to produce a clear result and answer the question of how the Palestinian accession to the International Criminal Court will affect Israeli military behavior in the Gaza strip. Called the study period ${ }^{(i)}$. The researcher has identified two areas for comparison in the two study periods. Which are 1- Analysis and comparison of the number of Palestinian casualties in the Gaza Strip. 2. Analyzing and comparing the types of targets that the occupation 
forces intended in the Gaza Strip. The researcher has divided categories within each field. The first field consists of dead and wounded, then details them into women, children and others. The second field, the researcher divided it into six categories: the category of citizens, workers and anglers, the category of peaceful demonstrators, the category of residential houses and civilian installations, the agricultural or borderlands category, the resistance class or resistance sites, and finally the category of cars and motorcycles. Then the comparison between all fields in two study periods. With the aim to come out more precisely and clearly, whether there are any changes in Israeli military behavior toward civilians in the Gaza Strip?. As it well known to the specialists that IDF has committed systematic and massive violations in the Gaza Strip, both of human rights principles and of international humanitarian law, as has been pointed out in numerous international reports ${ }^{\text {(iii) }}$ in particular of its deliberate targeting of civilian populations and property.

The researcher has relied on official and documented statistics, which are neutral and scientific evidence, and the researcher has relied on the reports of the Palestinian human rights centers, notably Al-Mezan Center for Human Rights and the Palestinian Center for Human Rights. If the statistics differ between them, Al-Mezan center was the first presented for its quality of classification, the graphs and the illustrations in its annual reports, special reports, and is considered a strong basis to be inferred and results to be extracted. Therefore, the scientific method for this study is the statistical method and the comparative analytical method.

\section{Theoretical framework and literature review:}

Some studies have focused on analyzing and comparing the level of commitment of the warring forces to the application of the articles of the conventions on the protection of civilians, and the obligation not to target them with direct attacks during armed conflicts (Valentino, Hutha, \& Croco, 2006) ${ }^{(\mathrm{iv})}$. The study statistically and analytically reviewed the data and numbers of victims resulting from all the wars that took place during a century from 1900 to the year 2003. The researchers compared the numbers of civilian casualties, and classified them into civilians and military without further classifications within the civilian category. (Charlie Carpenter, 2005) ${ }^{(\mathrm{v})}$ addressed the issue of protection provided by international law to vulnerable groups in society, such as women, children, the elderly, and the sick, but he opposed the idea of focusing on these groups only in reports and media statements because, from his viewpoint, this would harm the protection of adult male civilians not participating in hostilities. (Wood, Kathman and Gent, 2012) ${ }^{(\mathrm{vi})}$ were interested in showing the relationship between the conflict environment and the level of civilian harm during armed combat operations, and the study, which dealt with armed conflict situations between the years 1989 and 2005, showed that there is a relationship between the political environment of situations of conflict over power or the shifting balance of power or interventions On the one hand, and between the level of civilian harm on the other hand. The comparison was limited to the issue of harming civilians in general, without going into classifications within this category. While other studies dealt with the implications of these Israeli attacks on the rights guaranteed by international humanitarian law, (Adnan Abu Aamer) ${ }^{\text {(vii) }}$ a statement of the civil and political rights violated by the Israeli attacks on the Gaza Strip during the first Palestinian uprising between 1987 and 1993. While (Alsarhi, Abdul Rab, Yusof) ${ }^{\text {(viii) }}$ focused on a statement of the effects of these attacks on the rights guaranteed by a specific agreement. The study dealt with one topic, which is the Israeli violations against places of worship in the Gaza Strip and the position of international humanitarian law on that, in accordance with the 1954 Hague Convention for the Protection of Cultural Property, which showed the extent of the grave violations committed by the Israeli occupation forces to this convention. Almost the same, (Raed Ahmad Salha) ${ }^{(i x)}$ explained the effects of the Israeli attacks on the Gaza Strip on the Palestinian human right to adequate housing. In addition to a detailed explanation supported with statistics of what these attacks caused in the creation of a major housing crisis in the Gaza Strip. This is due to the destruction of thousands of Palestinian homes and dwellings of Palestinian civilians, and the tightened siege on the Gaza Strip has increased the crisis due to preventing or reducing the entry of building materials into the Gaza Strip. The study covered all the attacks that occurred on the Gaza Strip between 2008 and 2012, in addition to the issue of protection for civilian personnel in periods of international and non-international armed conflicts. On the other hand, other studies have focused on highlighting the position of international humanitarian law and the conventions that they have signed, such as the Geneva Convention of 1949. As for the issue of classification and analysis of the Israeli attacks and their statistical consequences, the attention of human rights centers in Palestine has increased in the last two 
decades. Statistical tables and charts that detail, classify and clarify the numbers of victims, their ages, sexes and types, the country and the location of the injury, its type, the sex of the victim, and so on, appeared remarkably in its annual reports. As for the comparison between two equal periods, these reports were not concerned only with comparing the numbers of victims for the year covered by the report with the previous year only. All of this, perhaps, with the aim of showing the extent of Israeli violations against Palestinian civilians, and indicating the many rules and agreements that the Israeli army has violated the rules of international humanitarian law. Among the most important of these are the rule of distinction and the rules for protecting civilians, in addition to Israel's violation of its international obligations in accordance with the agreements it has signed and is a party to. For example, the Convention on the Rights of the Child of 1989, or the Convention on the Elimination of All Forms of Discrimination Against Women of 1979, in addition to the Geneva Conventions of 1949. Hence, the idea of preparing statistical tables developed at the Al Mezan Center for Human Rights in the Gaza Strip. The aim is to further separate and categorize the categories of victims, including the dead and wounded, according to gender, or according to the place of injury in the body, or according to the weapon used in the assault. Noting that statistical aspects, tables and graphs distinguish the reports of human rights institutions on the Israeli attacks, while university studies are characterized by more analysis and explanation. As for this study, it is concerned with comparison and statistical analysis in detail of the number of victims, their ages, and their sexes in each period. In addition to a simplified analysis, and an explanation of the big and exciting changes between the two periods, as will be explained later. In addition to a breakdown of the objectives that these attacks hit, whether they are houses, lands, citizens, resistance fighters, etc., all of this is aimed at clarifying the size and quality of any changes in the Israeli attacks on the Gaza Strip between the two study periods.

\section{1: Analysis and comparison of the number of Palestinian victims in the Gaza Strip in both periods}

This study as said before focuses on presenting and analyzing the numbers of Palestinian victims, especially the dead and injured, before and after Palestine's accession to the International Criminal Court ${ }^{\mathrm{x}}$ These are $^{2}$ highly professional reports ${ }^{(\mathrm{xi})}$ This has been divided into two sections:

\section{1: Analysis of the numbers of victims in both periods}

The following tables (1) and (2) provide a statistical summary based on monitoring, documentation and field research carried out by human rights institutions in the Gaza Strip.

Table - 1

\begin{tabular}{|c|c|c|c|c|}
\hline \multicolumn{5}{|c|}{ Palestinian victims during the first period (2010-2014) } \\
\hline Year & $\begin{array}{l}\text { Women }{ }^{(x i i)} \text { and } \\
\text { children }^{\left({ }^{(x i i i)}\right.}{ }^{\text {killed }}\end{array}$ & $\underset{\text { (xiv) }}{\text { Others killed }}$ & Total killed & Total wounded \\
\hline $2010^{) \times v(}$ & 5 & 67 & 72 & 209 \\
\hline${ }^{(\mathrm{xvi})} 2011$ & 15 & 99 & 114 & 467 \\
\hline (xvii) 2012 & 56 & 196 & 252 & 1473 \\
\hline (xviii) 2013 & 2 & 10 & 12 & 75 \\
\hline${ }^{(\mathrm{xix})} 2014$ & 862 & 1418 & ${ }^{(\mathrm{xx})} 2280$ & 11724 \\
\hline Total & 940 & 1790 & 2730 & 13948 \\
\hline
\end{tabular}

It should be recalled that 2012 witnessed the wide Israeli military attack known as (Operation Pillar of Cloud/ Sajil Stone) ${ }^{(x x i)}$, which lasted eight days from 14 to 21 November 2012. 179 people were killed, and that explains the relative rise in the number of victims compared to 2011.

In 2013, the number of victims is clearly low, obviously due to two reasons: the regional role of Egyptian diplomacy in the time of the president Mohamed Morsi and the military coup in Egypt. Where the Minister 
of Defense (Abdel Fattah Al-Sisi), who is close to Israel, overthrew President (Mohamed Morsi), Israel was careful not to raise any issues due to the uncertainty in Egypt.

The year 2014 saw a significant increase in the number of victims, perhaps highest since the occupation in 1967, as the year witnessed the longest of battles between Israel and the Palestinian resistance that lasted 51 days. During the war the Israeli army carried out all forms of aggression and used all kinds of weapons, missiles, artillery and explosives. This has left a large number of victims as well as extensive destruction of infrastructure, housing and civilian installations in every the cities and towns of the Gaza strip . (xxii)

\begin{tabular}{|c|c|c|c|c|}
\hline \multicolumn{2}{|c|}{ Table -2 Palestinian victims after Palestinian accession to ICC (from 2015 to 2019) } \\
\hline Year & $\begin{array}{c}\text { Women and children } \\
\text { killed }\end{array}$ & Others killed & Total killed & Total wounded \\
\hline (xxii) $2015^{(\text {xxiv) } 2016}$ & 5 & 23 & 28 & 1275 \\
\hline${ }_{(\text {xxv) } 2017}$ & 4 & 5 & 9 & 221 \\
\hline (xxvi) $2018^{(x x v i i)} 2019$ & 52 & 26 & 29 & 902 \\
\hline $\begin{array}{c}\text { Total second } \\
\text { period }\end{array}$ & 30 & 78 & 108 & 13946 \\
\hline
\end{tabular}

It is easy to note that in the three years following the Palestine's accession to the International Criminal Court (ICC), 2015, 2016 and 2017, the number of victims was low compared to 2018 and 2019. Even the increase in 2018 and 2019 is not comparable to that of the pre-accession period. It is explained by the Israeli army's decision to block the Return Marches ${ }^{\text {(xxviii) }}$ considering it a real danger to its existence. The Israeli occupation forces confronted the marches with lethal excessive force, which led to a noticeable increase in the number of victims in 2018, yet less than the number of victims of the year 2019.

\section{2: Comparison of the number of victims between the pre-accession period and beyond}

\subsection{1: Comparing the number of dead $^{(\mathrm{xxix})}$ in general in the two periods}

Table -3 and Figure -1 summarize and illustrate this comparison.

\begin{tabular}{|c|c|c|}
\hline \multicolumn{2}{|c|}{ Table-3 number of deaths from 2010-2019 } \\
$(\mathrm{xxx})$
\end{tabular}

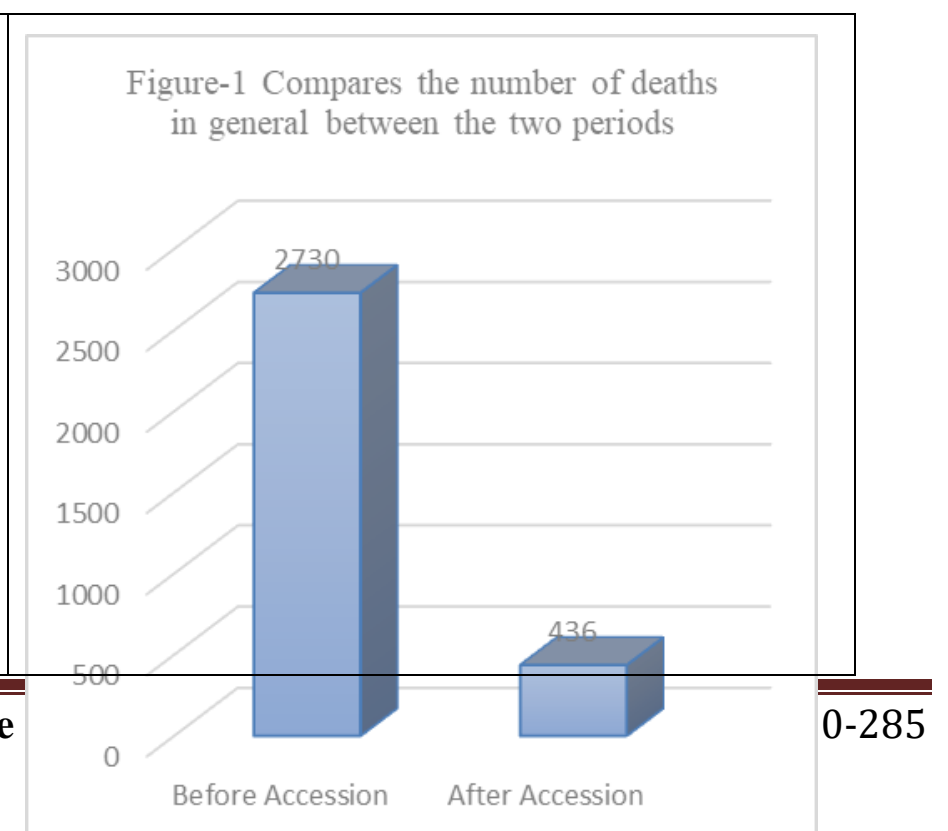




\begin{tabular}{|c|c|c|c|}
\hline $\begin{array}{c}\text { Percentage } \\
\text { of those } \\
\text { killed in } \\
\text { each period }\end{array}$ & $86 \%$ & $14 \%$ & \\
\hline
\end{tabular}

The large decrease in the number of deaths in the second period in comparison with the first period is obvious. The total number of deaths in the first period is 2730 and it decreased to 436 in the second period, $i$ e. the first period deaths were nine times more as shown in the figure 1 .

\subsection{2: The number of women and children killed in the two periods (xxxi)}

The researcher has focused on the number of woman and child victims in particular as these two categories represent civilians ${ }^{(\mathrm{xxxii})}$. Israeli authorities cannot claim that it targeted them because they were engaged in hostilities. Targeting women and children command more attention from the International community, and there were many international conventions for protecting them from the scourge of war. Despite all that, they are still among the most affected groups of wars and conflicts. (xxxiii) The Israeli conduct on the ground does not show respect for these international conventions or norms. Table 4 and figure 2 illustrate this comparison.

\begin{tabular}{|c|c|c|}
\hline \multicolumn{2}{|c|}{$\begin{array}{c}\text { Table4: Numbers of women and children } \\
\text { killed in the two periods }\end{array}$} \\
\hline $\begin{array}{c}\text { Thxiv) } \\
\text { periods }\end{array}$ & $\begin{array}{c}\text { First } \\
\text { period } \\
\text { 2010-2014 }\end{array}$ & $\begin{array}{c}\text { Second } \\
\text { period } \\
\mathbf{2 0 1 5}-2019\end{array}$ \\
\hline $\begin{array}{c}\text { Total } \\
\text { number of } \\
\text { women and } \\
\text { children } \\
\text { killed }\end{array}$ & 940 & 94 \\
\hline $\begin{array}{c}\text { Percentage } \\
\text { of women } \\
\text { and children } \\
\text { killed }\end{array}$ & $91 \%$ & $9 \%$ \\
\hline
\end{tabular}

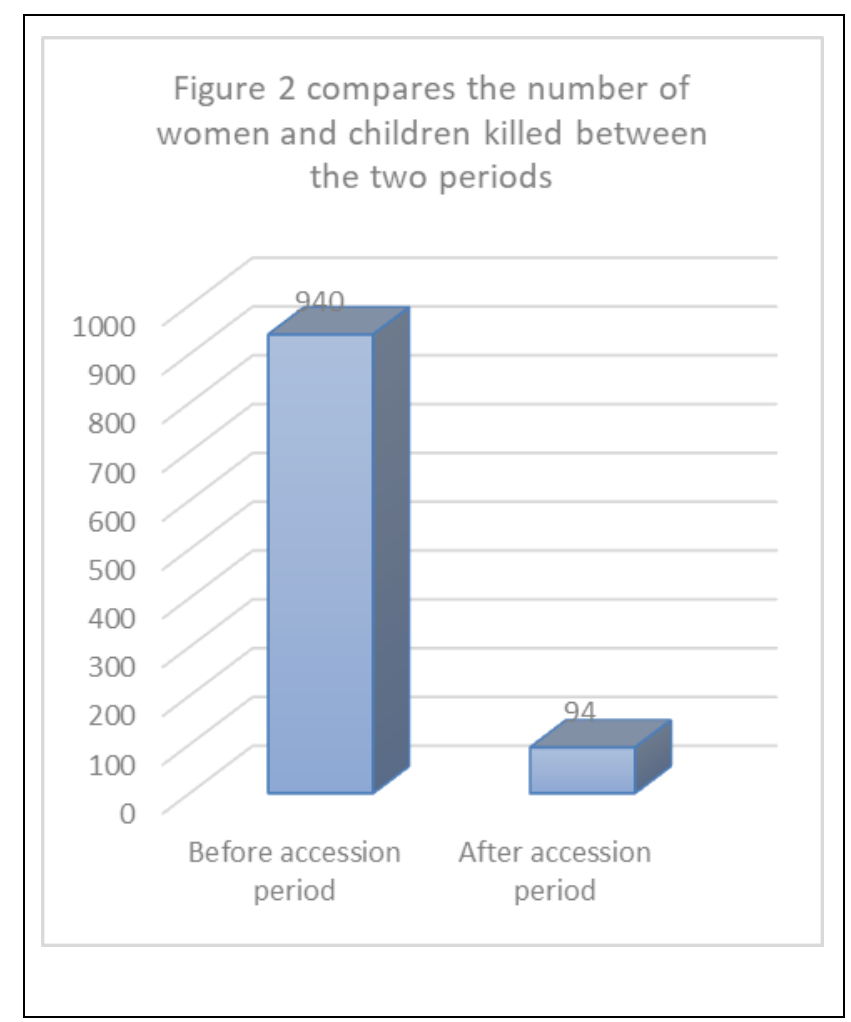

\subsection{3: Comparison of the percentage of woman and children killed to the rest of the victims in the two periods}

It is clear from table 4 that out of 2,730 killed during first period the number of women and children is 940 , which represents about $34.4 \%$ of the total while in the second period is is 94 , out of 436 total deaths. The total number of people killed during the second period $21.6 \%$ of the total deaths.

This is another decrease besides the number of casualties. Here also out of the total number of deaths, the percentage of women and children killed decreased significantly, as shown by the figure 3 and 4 . 


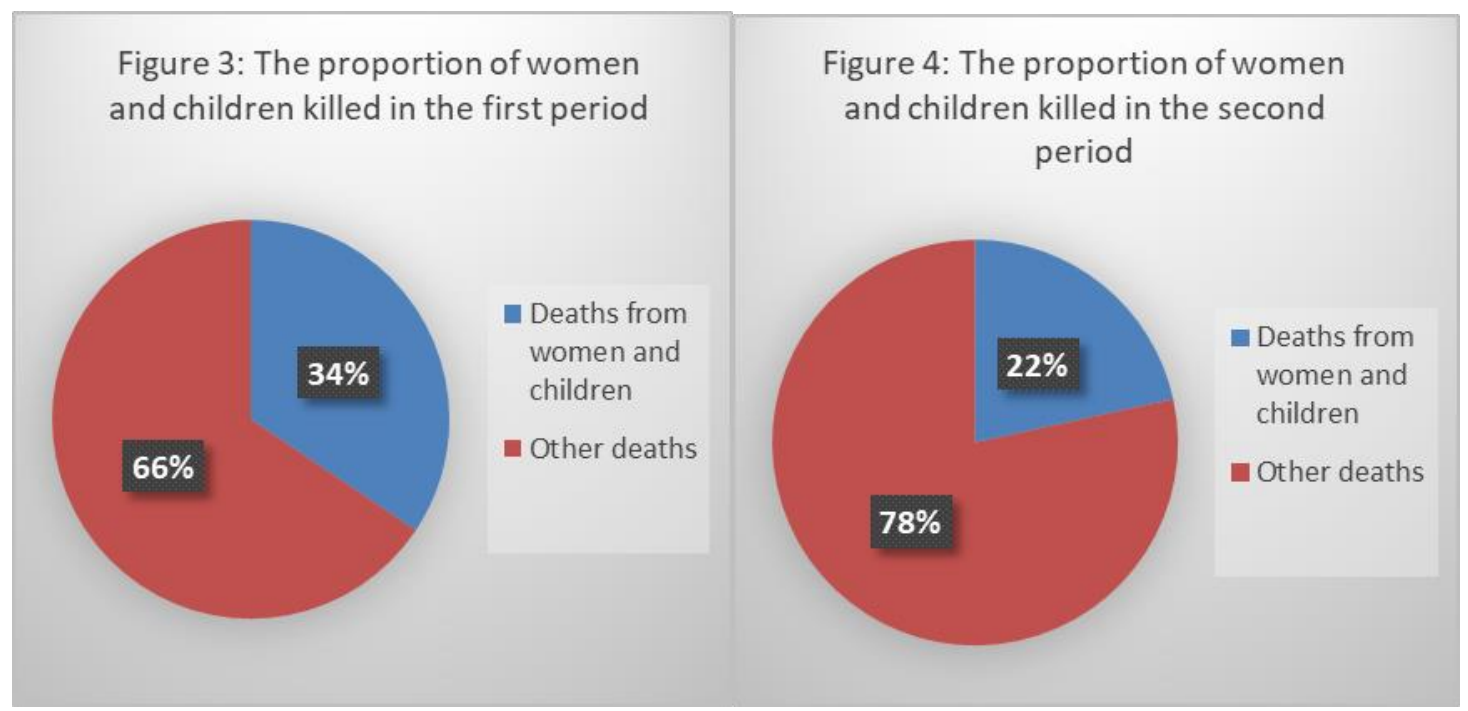

1.2.4: The ratio of the injured to the that of the dead in the two periods

A comparison of the number of the injured to that of the killed in the two periods shows that there is increase in the period following accession, with the number of injured in the first period (13948) rising to (22165) injured making a total of (36113). That is the second period witnessed more than $61 \%$ increase in the number of wounded. See Table (5) Chart number (5)..

\begin{tabular}{|c|c|c|}
\hline \multicolumn{2}{|c|}{$\begin{array}{c}\text { Table 5: Comparing the number of dead to the } \\
\text { number of injured during the years in the two } \\
\text { periods }\end{array}$} \\
\hline Pxx) & $\begin{array}{c}\text { First } \\
\text { Period } \\
2010-2014\end{array}$ & $\begin{array}{c}\text { Second } \\
\text { Period } \\
2015-2019\end{array}$ \\
\hline $\begin{array}{c}\text { Total deaths per } \\
\text { period }\end{array}$ & 2730 & 436 \\
\hline $\begin{array}{c}\text { Total injured in } \\
\text { each period }\end{array}$ & 22165 & 13948 \\
\hline $\begin{array}{c}\text { Ratio of the injured } \\
\text { to the dead in each } \\
\text { period is }\end{array}$ & 5 Times & 51 Times \\
\hline
\end{tabular}

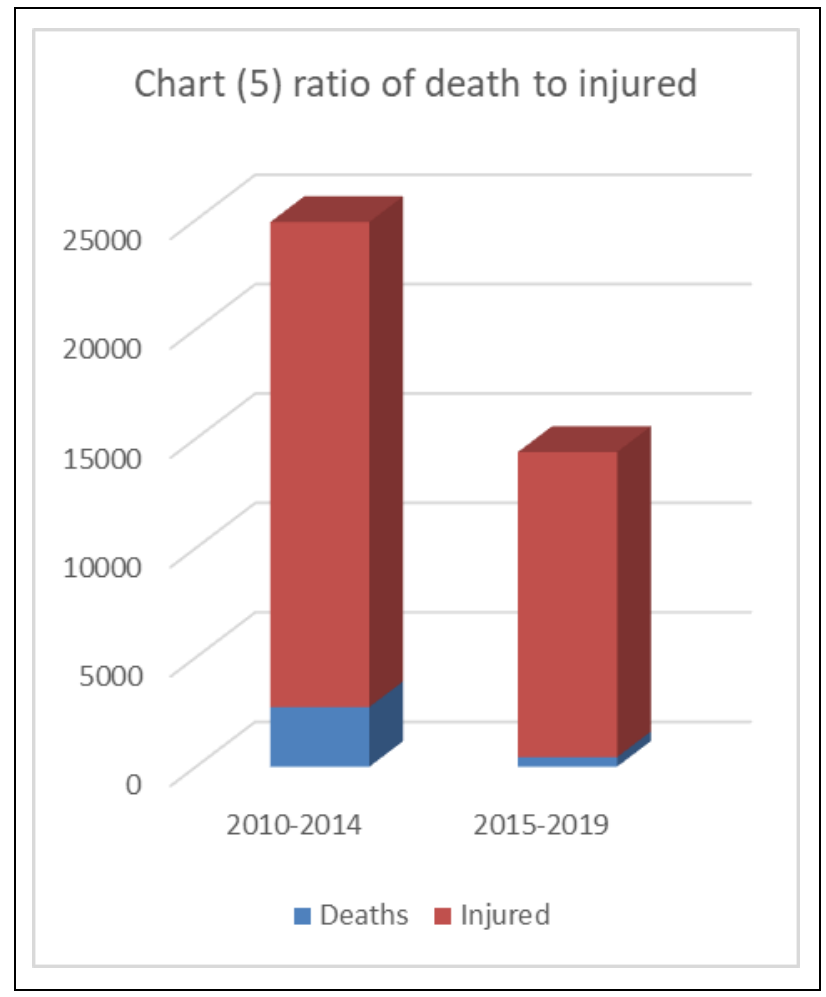

When the proportion of those killed to injured is compared in each period, it is noted that the ratio of injured to dead of the total victims increased significantly in the second period, and doubled considerably, as the ratio of the injured to the dead in the first period represented about (5.1 times), i.e. that every (10) dead is being met (51) injured, and in the second period it became about (50.8 times). In other words, every (10) dead (508) injured, which shows Israel's fear of more deaths, and the more attention the international community represents, for example, the latest report of the UN fact-finding Commission ${ }^{\text {(xxxvi) }}$,interested in showing the number of people killed in the protests known as (Great return Marches), and they are (189) deaths among the demonstrators, until the end of 2018, and the media did not care to show the large 
numbers of the injured, who are more than thirteen thousand injured, and although both are considered a crime under international humanitarian law, however the biggest concern is the number of people killed, which Israel has been keen to reduce considerably.

It's worth mentioning that most of the wounded in the second period occurred in 2018 - 2019, with 13,946 injured during 2018, while (5821) injured in 2019 due to firing on Return Marches.There is significant increase in the number of injured, and the percentage of the wounded this year alone, was more than $89 \%$ in the second period!.

\section{2: Analysis of the objectives of Israeli forces in Gaza Strip in the two periods}

In terms of the objectives of the military forces of Israel and its military arms, they are numerous and varied. In order to bring the image closer and for comparison purposes in a normative manner, the researcher has divided into six categories:

1. Citizens :These are civilians who lead their normal everyday lives, including Palestinian farmers, cattle herders, gravel collectors, plastic collectors and fishermen.

2. Peaceful protestors :These are the Palestinian protesters who go near the borders to demand lifting of the unfair blockade imposed on Gaza Strip. Although they are supposed to be in citizen category, the researcher has assigned an independent category to show the big changes that occurred there.

3. Residential houses and civilian facilities :These include residential apartments, buildings, residential towers, villas and rural houses, the civilian establishments include all public facilities such as hospitals, clinics, mosques, schools and universities, headquarters of various ministries, banks, police and civil defense centers, commercial and industrial establishments.

4. Agricultural land or border areas :They include farms, nurseries, petals, empty uninhabited areas, border strip with Egypt, and areas close to the border between the Gaza Strip and Israel.

5. Resistance elements or resistance locations: Resistant is the person who is an active participant in the main or secondary hostilities working with Palestinian resistance groups which are in direct confrontations with the Israeli occupation forces. This category also includes the training sites of resistance factions, training camps and resistance observation posts near the border. This category also include all persons targeted by the occupation forces by assassination and are known to belong to resistance groups and participate in the hostilities continuously or intermittently. They may or may not be in confrontation at the moment they are targeted.

6. Cars or motorcycles :They include all kinds of standard civilian Cars, trucks of all size, buses of different kinds, and motorcycles of either two or three wheels.

\section{1: Analysis and elaboration of the objectives of the Israeli forces in both periods}

The following two Tables, 10 and 11, provide in detail the preparation and quality of the targets that Israeli forces are pursuing during in two study periods in consideration.

Table (10) the types of targets that have been targeted by the occupation forces during the years 2010-2014

\begin{tabular}{|c|c|c|c|c|c|c|c|}
\hline $\begin{array}{l}\text { Types of } \\
\text { Targets }\end{array}$ & $\begin{array}{c}\text { Citizens, } \\
\text { workers } \\
\text { and } \\
\text { fisherme } \\
\text { n }\end{array}$ & $\begin{array}{c}\text { Peacef } \\
\text { ul } \\
\text { demon } \\
\text { strator } \\
\quad \text { S }\end{array}$ & $\begin{array}{c}\text { Residenti } \\
\text { al houses } \\
\text { or civilian } \\
\text { establish } \\
\text { ments }\end{array}$ & $\begin{array}{c}\text { Agricultu } \\
\text { ral or } \\
\text { border } \\
\text { land }\end{array}$ & $\begin{array}{c}\text { Resistanc } \\
\text { e } \\
\text { elements } \\
\text { or } \\
\text { resistance } \\
\text { locations }\end{array}$ & $\begin{array}{c}\text { Cars and } \\
\text { motorcyc } \\
\quad \text { les }\end{array}$ & $\begin{array}{c}\text { Total } \\
\text { objectiv } \\
\text { es }\end{array}$ \\
\hline )xxxviii(2010 & 144 & 33 & 214 & 189 & 11 & 13 & 604 \\
\hline (xxxviii) 2011 & 299 & 108 & 115 & 118 & 243 & 24 & 907 \\
\hline$\left({ }^{(x x x i x)} 2012\right.$ & 1222 & 48 & 2846 & 206 & 522 & 94 & 938 \\
\hline
\end{tabular}




\begin{tabular}{|c|c|c|c|c|c|c|c|}
\hline${ }^{(\mathrm{xl})} 2013$ & 99 & 0 & 26 & 60 & 20 & 2 & 207 \\
\hline${ }^{(\mathrm{xli})} 2014$ & 9411 & 48 & 35504 & 2213 & 4145 & 1178 & 52499 \\
\hline $\begin{array}{c}\text { Total First } \\
\text { period }\end{array}$ & 11175 & 237 & 38705 & 2786 & 4941 & 1311 & 59155 \\
\hline
\end{tabular}

Table 11 the types of targets that have been targeted by the occupation forces during the years 2015-2019

\begin{tabular}{|c|c|c|c|c|c|c|c|}
\hline $\begin{array}{c}\text { Types of } \\
\text { Targets }\end{array}$ & $\begin{array}{c}\text { Citizens, } \\
\text { workers } \\
\text { and } \\
\text { fisherme } \\
\text { n }\end{array}$ & $\begin{array}{c}\text { Peacef } \\
\text { ul } \\
\text { demon } \\
\text { strator } \\
\text { s }\end{array}$ & $\begin{array}{c}\text { houses or } \\
\text { civilian } \\
\text { establish } \\
\text { ments }\end{array}$ & $\begin{array}{c}\text { Agricultu } \\
\text { ral or } \\
\text { border } \\
\text { land }\end{array}$ & $\begin{array}{c}\text { Resistanc } \\
\mathbf{e} \\
\text { elements } \\
\text { or } \\
\text { resistance } \\
\text { locations }\end{array}$ & $\begin{array}{c}\text { Cars and } \\
\text { motorcyc } \\
\text { les }\end{array}$ & $\begin{array}{c}\text { Total } \\
\text { objectiv } \\
\text { es }\end{array}$ \\
\hline (xlii) $2015^{74}$ & 1222 & 5 & 38 & 40 & 0 & 1379 \\
\hline (xliii) $2016^{7(x l i v)} 2017$ & 94 & 763 & 6 & 61 & 101 & 0 & 1025 \\
\hline (xlv) $2018^{165}$ & 13913 & 29 & 106 & 169 & 3 & 14385 \\
\hline 2019)xlvi( & 192 & 5536 & 425 & 60 & 120 & 1 & 6334 \\
\hline $\begin{array}{c}\text { Total } \\
\text { second } \\
\text { period }\end{array}$ & 596 & 21618 & 469 & 340 & 437 & 4 & 23464 \\
\hline
\end{tabular}

It is worth mentioning that those who were classified as resistance elements were not in military circumstances or during fighting. Some of them were targeted while he/she was in his house, on street, in the car, or other in civil circumstances. While international humanitarian law does not justify targeting those who do not carry its weapons and not participate in hostilities. Such crimes are classified as extrajudicial murders and outlaw killings. Article 15 of the Fourth Geneva Convention prohibits and protects the targeting of indirect combatants in hostilities or the sick and wounded from them. ${ }^{\text {(xlvii) }}$

The previous two tables show a significant decline in the number of targets hit by the Israeli occupying forces in the second period, with the exception of the group of peaceful demonstrators, which increased significantly in 2018 and 2019 due to the major return marches.

\section{2: Comparing the numbers and type of objectives between the two periods}

\subsection{1: compare the numbers and the ratio of targets in both periods}

Table 12 and Figure 11 summarize and illustrate this comparison.

Table 12 comparing the numbers of targets for the two periods

\begin{tabular}{|c|c|c|c|}
\hline $\begin{array}{c}\text { Two } \\
\text { periods }\end{array}$ & $\begin{array}{c}\text { Period } \\
\text { before } \\
\text { Palestine's }\end{array}$ & $\begin{array}{c}\text { Period } \\
\text { after } \\
\text { Palestine' }\end{array}$ & $\begin{array}{c}\text { Two } \\
\text { periods } \\
\text { togethe }\end{array}$ \\
\hline
\end{tabular}

Graph 11: Ratio of intended targets in both periods

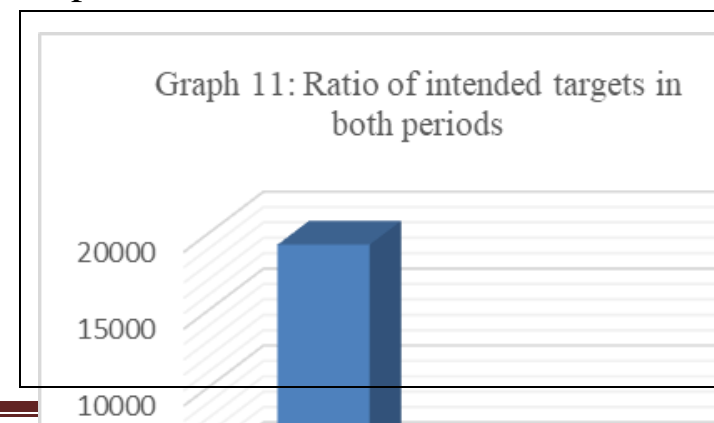




\begin{tabular}{|c|c|c|c|}
\hline & joining & $\mathrm{s}$ joining & $\mathbf{r}$ \\
\hline $\begin{array}{c}\text { Total } \\
\text { number of } \\
\text { targets }\end{array}$ & 59155 & 23464 & 82619 \\
\hline Percentage & $71.6 \%$ & $28.4 \%$ & $\% 100$ \\
\hline
\end{tabular}

The table and figure above show that the targets deliberately bombed by the occupation forces in the first period reached 59155, which represent about $71.6 \%$ of the total targets of the two periods. At the same time the targets that were bombed in the second period is 23464 , which represent $28.4 \%$ of all targets in the two periods. This gives further evidence of the significant change in Israeli military behavior toward the Gaza.

Excluding the peaceful protesters of both periods - which is in a different political context - the injured targets in the first period were 58918; at the same time in the second period, it is 1846, which that represent $3 \%$ of the total injured goals in the two.

\subsection{2: Detailed comparison of the number of each target between the two periods}

Table 13 and figure 12, 13 and 14 shows this comparison between the two periods in detail.

\begin{tabular}{|c|c|c|c|}
\hline \multicolumn{3}{|c|}{ Table -13: Comparison of ratio of each target in the two periods } \\
\hline Type of Target & $\begin{array}{c}\text { Before Palestine joined } \\
\text { the court }\end{array}$ & $\begin{array}{c}\text { After Palestine joined the } \\
\text { court }\end{array}$ & $\begin{array}{c}\text { Two periods } \\
\text { together }\end{array}$ \\
\hline $\begin{array}{c}\text { Citizens, workers and } \\
\text { fishermen }\end{array}$ & 11178 & 596 & $5 \%: 95 \%$ \\
\hline $\begin{array}{c}\text { Peaceful protestors } \\
\text { Residential houses or } \\
\text { civilian establishments }\end{array}$ & 237 & 21618 & $99 \%: 1 \%$ \\
\hline $\begin{array}{c}\text { Agricultural, empty or } \\
\text { border land }\end{array}$ & 38705 & 469 & $1 \%: 99 \%$ \\
\hline $\begin{array}{c}\text { Resistance elements or } \\
\text { resistance locations }\end{array}$ & 2786 & 340 & $11 \%: 89 \%$ \\
\hline $\begin{array}{c}\text { Motorcycles or cars } \\
\text { (1) }\end{array}$ & 1311 & 437 & $8 \%: 92 \%$ \\
\hline
\end{tabular}




\begin{tabular}{|l|l|l|l|}
\hline Total & 23464 & 59155 & $28 \%: 72 \%$ \\
\end{tabular}

Figure 13 show a significant decline in all targets from all types substantially, except in the peaceful protestors' category. Targeting some types (motorcycles, cars and residential houses) remarkably decreased reaching almost zero in the second period, indicating a marked change in Israeli military behavior. It is to be remembered that the targeting of civilian installations and civilian property per se is a war crime, according to the Fourth Geneva Convention.

On the contrary, the targeting the category of peaceful protesters jumped dramatically. While in the first period about 237 were targeted, in the second period reached it reached a dramatic 21618, representing approximate $99 \%$ of the targeting in both periods. In 2018 largest share spiraled, followed by that in 2019. This two year's share constitutes $90 \%$ of targeting of protesters in the second period.

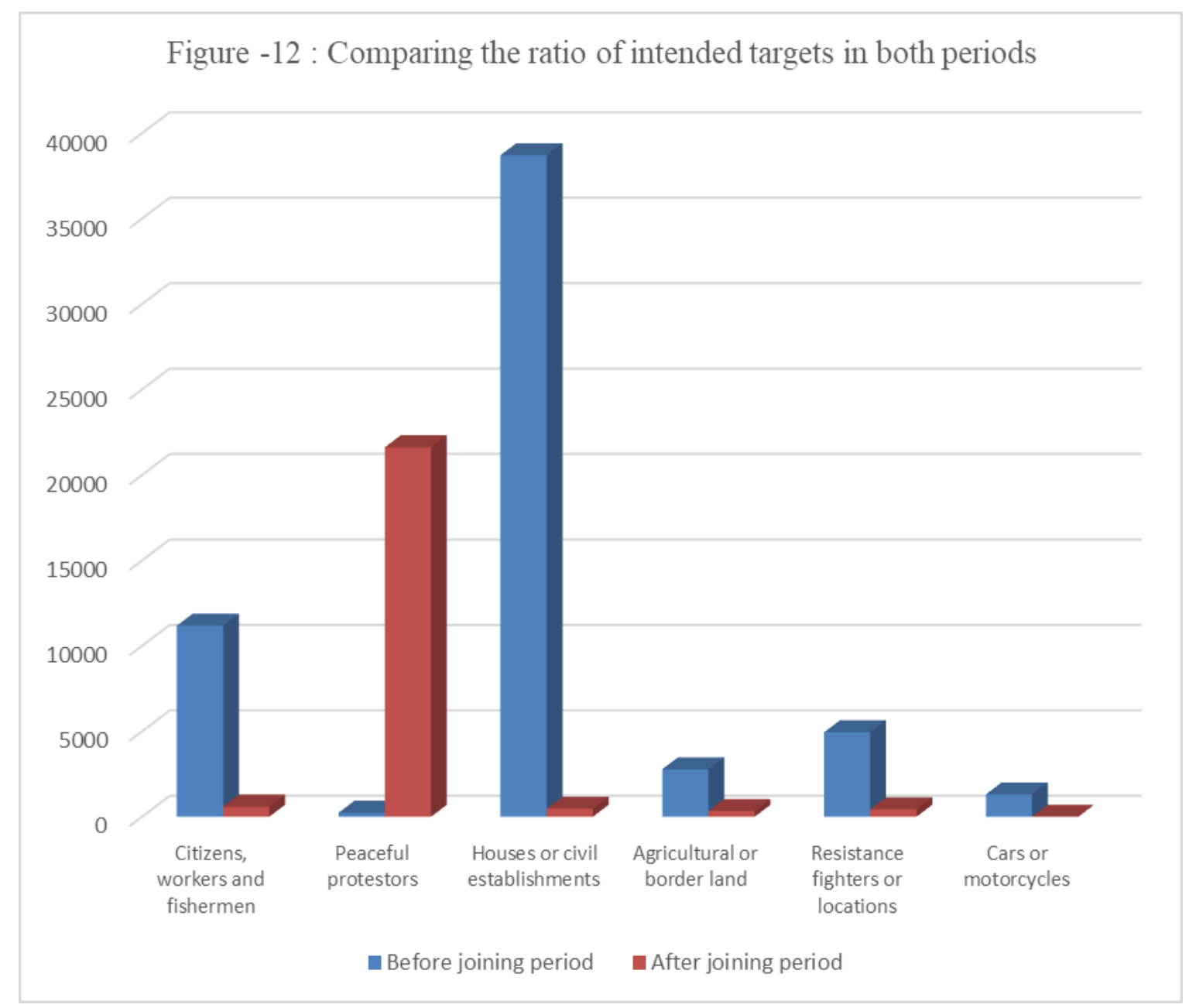

However, if we look at the most targeted categories within each of the two periods, the figures 12 and 14 , there is a clear change of the type of targets adopted by the occupation forces in the second period. While some categories appeared, some disappeared, some showed significant decline while others dramatically increased. This confirms the fact that The Israeli occupation forces have changed their military behavior towards the Gaza Strip in terms of quantity and quality. 


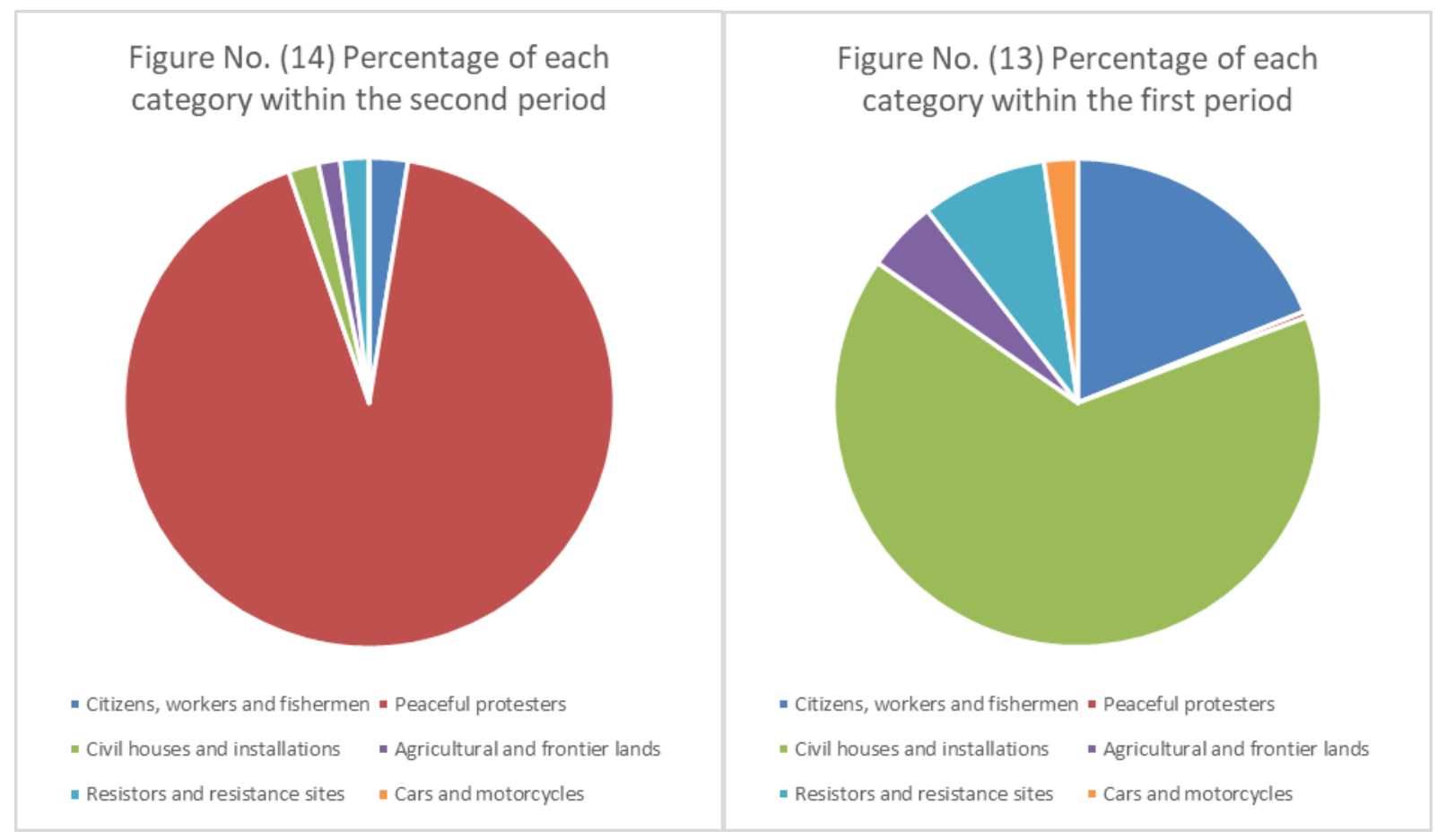

Whereas the most targeted groups in the first period were homes and establishments followed by citizens and workers and then the land category. A significant change happened in the in the second period, where category of peaceful demonstrators, which was the least targeted group in the first period, became the most targeted group in the second period, followed by the homes and establishments, followed the resistance and their locations.

\subsection{3: Recapitulation:}

It is inferred from the previous statistics that there is no room for doubt that Israel has taken into account the subject of the International Criminal Court. Data for the two study period, which is ten years, categorically establishes it. The data showed conclusively that the years from 2015 to 2019 witnessed a significant decline in the number of Palestinian fatalities, especially the number of women and children killed. It also showed the number of Israeli military attacks on the Gaza Strip declined significantly, particularly, heavyweapons attacks from air and artillery bombardment. The number of Palestinian targets attacked by Israeli army forces has also decreased considerably, especially targeting of residential buildings, homes and civilian installations, as well as the deliberate bombardment of civilian vehicles.

Although other influencing factors were in favor of the occupation, especially the regional and political factors and the unprecedented American support, the IDF has reduced targeting the urban objects in proportions, and it can therefore be said that this is a strong indication of the importance of what the Palestinians have as a tool to deter Israeli violations of international humanitarian law.

While acknowledging that the instrument did not stop attacks against civilians in the Gaza Strip altogether, the natural conclusion has to be that the attacks have decreased considerably in quantity and type. The previous statistics are the best evidence.

\section{Conclusion}

From the previous statistics it is undoubtedly concluded; that Israel is reckoning the International Criminal Court, and that is according to the data of the two 10-year study periods, the five years before the accession has witnessed two wars and a large number of victims has fallen, but the period after accession has not. The data have made it abundantly clear that the years 2015-2019 have seen a significant decline in the number of Palestinian deaths, It was in the first period (2730) people, then it decreased to (436) people in the second period. and the proportion of women and children killed has also fallen, It represented about [34.4\%] of the total dead, down to about [21.6\%] of the total dead.

The number of targets targeted by the Israeli army has also decreased considerably, from targeting $(59,155)$ goals in the first period, which represents about $(71.6 \%)$ of the total goals in the two periods, then it declined 
in the second period to $(23,464)$ goals, which represents $(28.4 \%)$ of the total of all goals in the two periods. This coincided with a very significant decline in some categories, especially the targeting of residential buildings, homes and civilian facilities, from the targeting of (38705) in the first period, it decreased to (469) in the second period, in proportion to approximately $99 \%$ to $1 \%$. And the same applies to the deliberate bombing of civilian cars that retreated. From (1311) in the first period to only (4) in the second period.

This is therefore a strong indication of the importance of Palestine's accession to the Rome Charter. In the face of Israel's violations of international humanitarian law. While acknowledging that the Israeli military behavior may be controlled by several factors. This study is not an area to be discussed. However, this study is looking whether there are any changes in the number and type of Israeli attacks on the Gaza Strip, or not? In the event that these changes are proven, then this research confirms that if there are reasons for these changes, then Palestine's accession to the court will be one of them. With Note that this has not led to a total cessation of such violations and attacks against civilians in the Gaza Strip. However, the attacks have decreased significantly, in both quantity and type, the number of death casualties has decreased considerably, while injuries have increased, the quality and size of targets have changed, and the previous statistics are the best evidence.

\section{Reference:}

[1] It is not among the aims of this research to study and analyze the causes of these changes - if any - in the size and type of the Israeli attacks on the Gaza Strip, and the resulting casualties and losses. This is another research that may be based on the result of this research. We suggest a researcher who has relevance in studying the political, geopolitical and military aspects.

[2] For the purposes of this study, the two periods or two of the study period are those chosen in this study to compare Israeli behavior before and after Palestine accession to the International Criminal Court at the beginning of 2015, the first period includes five years from the beginning of 2010 to the end of 2014. The period is sometimes called the pre-accession period, and the second period is also five years, from the beginning of 2015 to the end of 2019, which is called the post-accession period.

[3] Richard Falk. 2014. "Report of the Special Rapporteur on the situation of human rights in the Palestinian territories occupied since 1967". Human Rights Council. Twenty-fifth session. Browsed on: 16/06/2018. See:https://www.securitycouncilreport.org/un-documents/document/ahrc2567.php

[4] Benjamin Valentinoa1, Paul Hutha2 and Sarah Croco, " Covenants Without the Sword International Law and the Protection of Civilians in Times of War", Cambridge journals: World politics, 3/4/2006, all right reserved by Princeton university, http://journals.cambridge.org/action/displayAbstract?fromPage=online \&aid=7694220\&fileId=S0043 887100020657

[5] R. Charli Carpenter, "Women, Children and Other Vulnerable Groups": Gender, Strategic Frames and the Protection of Civilians as a Transnational Issue", Article first published online: 25 APR 2005, Wiley Online Library, see: http://onlinelibrary.wiley.com/doi/10.1111/j.00208833.2005.00346.x/abstract

[6] Reed M Wood, Jacob D Kathman and Stephen E Gent, Armed intervention and civilian victimization in intrastate conflicts, Journal of Peace Research,DOI, 28 sep 2012, 10.1177/0022343312449032 2012 49: 647 , see: http://jpr.sagepub.com/content/49/5/647

[7] Adnan Abu Amer, (2004). The Israeli violations of Palestinian civil and political rights in the Gaza Strip during the First Intifada 1987-1993. (Master Thesis) Islamic University - Gaza http://hdl.handle.net/20.500.12358/17993

[8] Abd Alkarim Zuhair Alsarhi, Muneer Ali Abdul Rab, Arif Fahmi Md. Yusof. The Israeli Violations Against Places Of Worship In Gaza Strip And The Position Of International Humanitarian Law. eImtiyaz USIM Journals Malaysian Journal of Syariah and Law (MJSL) MJSL, Vol. 7, No.1, June 2019 
[9] Raed Ahmed Salha, The housing crisis in the Gaza Strip in light of the blockade and the attacks of the Israeli occupation during the period from 2007-2015: A study in housing geography, (Master Thesis) The Islamic University, 2016.

[10] The most famous of these institutions are the Al-Mezan Center for Human Rights, the Palestinian Center for Human Rights, the Al-Haq Foundation and the Addameer Foundation for Human Rights.

[1] The reports of international organizations rely heavily on them in the preparation of their reports, especially since these institutions have research and investigation teams scattered throughout the territory of the cities and towns of the Gaza Strip, and they have a methodology in collecting, scrutinizing and entering data into a computerized information system subject to scrutiny and review prior to publication, and for more information on the methodology of collecting data for these institutions see the report "Aggression in Numbers 2014", jointly prepared by these institutions, p. 59. Browsing date: 22/02/2019. See :http://www.mezan.org/uploads/files/1448259764820.pdf

[2] Women: i.e. females over the age of 18 without regard to social status, whether married or otherwise.

[3] Children: Any person who has not attained the age of 18 years is of both sexes, as defined by the 1989 Convention on the Rights of the Child.

[4] Others: the rest of the victims, not women and children, who include civilians of other categories and ages, as well as resisters.

[5] 2011. "Annual Report 2010". Gaza: Palestinian Center for Human Rights. P.18, see http://www.pchrgaza.org/files/annual/arabic/annual\%202010.pdf.

[6] 31/01/2012 "Field report that monitors and documents violations of human rights by the Israeli occupying forces during the period from 1 January 2011 to 31 December 2011" Gaza: Al-Mezan Center for Human Rights. Gaza Strip. P.8.

[7] 2013, "Report on violations by Israeli occupying forces of the norms of international humanitarian law in their dealings with civilians in the Gaza Strip during 2012". Gaza: Al-Mezan Center for Human Rights. Gaza Strip. P.6.

[8] 2014. "Al Medan: A report on Israeli violations of international humanitarian law in the Gaza Strip during 2013." Gaza: Al-Mezan Center for Human Rights. Gaza Strip. P.6.

[9] 2014. "Annual Report Summary 2014". Gaza: Palestinian Center for Human Rights. P.6 .

[10] According to the Palestinian Center for Human Rights, there are (1591) civilian deaths, or about $70 \%$ of the total.

[11] TheSajil stones are the names of the Al-Qassam Brigades for that battle, while pillars of sky is the name of the Israeli army.

[12] United Nations. 22/06/2015. "The UN Commission of Inquiry on Gaza finds credible allegations that Israel and Palestinian armed groups committed war crimes in 2014." Human Rights Council. Browse on:

$18 / 06 / 2018$.

See:https://www.ohchr.org/AR/HRBodies/HRC/Pages/NewsDetail.aspx?NewsID=16119\&LangID= A

[13] 18/01/2016. "Report on Israeli occupation forces' violations of international humanitarian law and human rights law in Gaza Strip during 2015". Gaza: Al-Mezan Center for Human Rights. P.3.

[14] 2017. "Violations by the Israeli occupation forces of human rights and international humanitarian law in the Gaza Strip during 2016". Gaza: Al-Mezan Center for Human Rights. P.3.

[15] 2018. "Violations by the Israeli occupation forces of human rights and international humanitarian law in the Gaza Strip during 2017". Gaza: Al-Mezan Center for Human Rights. Gaza: Palestine, p. $4-$ 18.

[16] 2019. "Statistical report on Israeli occupation forces' violations of international humanitarian law and human rights principles in the Gaza Strip during 2018". Gaza: Al-Mezan Center for Human Rights. (Gaza). February 5. P.3-14.

[17] 2020. "From the field: A statistical report on violations by the Israeli occupation forces of the norms of international humanitarian law and the principles of human rights during the year 2019." Gaza: Al-Mezan Center for Human Rights. (Gaza). January 27. P.3. See: http://www.mezan.org/uploads/files/158010934487.pdf 
[18] It is the weekly peaceful marches that started from the date of the Earth Day anniversary on March 30th, where Palestinian youth are carrying out a series of protests in Gaza Strip. Near the border between the Gaza Strip and Israel, they are required to allow Palestinian refugees and their descendants to return to land from which they have displaced in what is now known as "Israel" and protest against the blockade of the Gaza Strip, and because the US embassy in Israel was moved from Tel Aviv to Jerusalem, protests intensified

[19] according to UN reports and human rights organizations "dead" was approved to be called upon the names of Palestinians whom they lost their lives, while the Palestinians' well-known name for the dead is martyrs.w

[20] This table was created from the previous table data in the previous two sections

[21] The researcher did not have statistics comparing the number of civilian deaths with the resistance for all years, so the researcher only compared the number of women and children killed, and for the years in which the number of civilian deaths and injuries was available were fixed in the tables 2012, $2014,2015,2016$. However, this could be replaced by a review of section III of the second case in comparing the number of attacks with air and artillery (heavy weapons), which cause large numbers of civilians to fall.

[22] Civilians are defined in accordance with the Fourth Geneva Convention: All persons who are not actively engaged in hostilities, whether directly facing, training, gathering information or providing logistical support, including those who are politically affiliated but whose roles are limited to noncombat activities. There was no doubt about their participation in support of the military effort.

[23] AmalYazgi. 2005. International Humanitarian Law and the Protection of Women and Children during Armed conflict, a collective author entitled: International Humanitarian Law: Perspectives and challenges, vol. 1, the Human Rights Law's Details and prospects, Beirut: Al-Halabi's Human Rights Publications, p.87.

[24] This table was created from previous table data in the previous two sections.

[25] This table was created from previous table data in the previous two sections.

[26] 28/02/2019. "UN committee refers to the possibility of committing war crimes by Israeli soldiers during the big return March". United Nations site. Browsed on: 26/04/2019. See: https://news.un.org/ar/story/2019/02/1028022

[27] From the ground: A field report on Israeli human rights violations in the Gaza Strip, 2010, previous reference

[28] 31/01/2012m. "A field report that monitors and documents violations by the occupying forces ... ". Al-Mezan Center for Human Rights. Previous reference.

[29] This schedule has been prepared from three reports: (1) Weekly Report. 2012.About Israeli violations in the Occupied Palestinian Territory. Gaza: Palestinian Center for Human Rights. Browse on: 22/02/2019. See :https://pchrgaza.org/ar/?cat=47, (2) 2013. "A comprehensive statistical report documenting: The death toll ... ". Al-Mezan Center for Human Rights. Previous reference. (3) 2013. "Report on violations by the Israeli occupying forces of the norms of international humanitarian law in their treatment ... ", Al-Mezan Center for Human Rights. Previous reference.

[30] 2014. "From the field: Report on violations by Israeli occupying forces ... In 2013, Al-Mezan Center for Human Rights. Previous reference. P.3-35.

[31] This table has been prepared from three reports: (1) 2014. "Annual Report Summary 2014". Gaza: Palestinian Center for Human Rights. Previous reference; (2) 2014. "From the field, a report on violations by the Israeli occupation forces of the rules of international humanitarian law in the Gaza Strip during the first half of 2014." Gaza: Al-Mezan Center for Human Rights; (3) [and the joint report] Al-Mezan Center for Human Rights, Al-Haq, Al-Ddameer Human Rights Foundation. Gaza: Palestinian Center for Human Rights.2015 "aggression in numbers: Previous reference

[32] 2016. "Report on violations by Israeli occupying forces ... In 2015". Al-Mezan Center for Human Rights. Previous reference.

[33] The table was prepared from two reports: 2017. "Violations by the Israeli occupation forces ... In 2016," al-Mezan Center for Human Rights. Previous reference. Also: 2017. "2016 Annual Report" 
Gaza: Palestinian Center for Human Rights. Browse on: 22/02/2019. See :https://pchrgaza.org/ar/wpcontent/uploads/2017/04/Annual-report-arabic2016.pdf.

[34] 2018. "Violations by the Israeli occupation forces ... During 2017," al-Mezan Center for Human Rights, former reference; also: 2018. "2017 Annual Report". Gaza: Palestinian Center for Human Rights. See : https://pchrgaza.org/ar/wp-content/uploads/2018/04/annual-arabic-2017.pdf.

[35] 2019. "Statistical report on Israeli occupation forces violations ... during 2018". Al-Mezan Center for Human Rights. Previous reference. P.8-10; also: 2018 Weekly Reports. Gaza: Palestinian Center for Human Rights. Browse on: 22/02/2019. See :https://pchrgaza.org/ar/?cat=47.

[36] 2020. "Statistical report about Israeli occupation forces violations... during 2019". Almezan center for human rights. Previous reference. P.8-10; also: 2019 weekly reports. Gaza: Palestinian center for human rights. See:https://www.pchrgaza.org/ar/?cat=47

[37] Article 15 states that any party to the conflict may propose to the hostile party, either directly or through neutral states or humanitarian body, the establishment of neutral zones in the territories where the fighting is taking place with a view to protecting the persons mentioned below from the dangers of combat without any discrimination :Wounded and sick combatants and non-combatants Civilian persons who do not take part in hostilities or carry out any action of a military nature during their stay in these areas.

[38] Once the parties to the conflict agree on the geographical location, management, financing and control of the proposed neutral area, a written agreement shall be concluded and signed by the representatives of the parties to the conflict. The agreement specifies the beginning of the neutralization of the region and its duration. 